\title{
NEGATIVE EFFECT OF PHOSPHOGYPSUM OVER PHYSIOLOGICAL ACTIVITY OF EARTHWORM EISENIA FETIDA
}

\author{
BeHERA, A. K.* - PATNAIK, A. \\ School of Life Sciences, Sambalpur University, Jyoti Vihar, Burla, Odisha 768019, India \\ (phone: +91-89-8423-7334) \\ *Corresponding author \\ e-mail: asitbehera10@gmail.com \\ (Received 22 $2^{\text {nd }}$ Mar 2018; accepted 27 $7^{\text {th }}$ Jun 2018)
}

\begin{abstract}
The study aimed to assess the genuine impact of phosphogypsum on the growth, feeding, respiration and regeneration of earthworm Eisenia fetida. In laboratory condition the earthworms were cultured under $0 \%$ (control), $4 \%, 8 \%$ and $10 \%$ concentration of phosphogypsum for 30 days. After completion of every 10 day changes in the above parameters were observed to track the impact of phosphogypsum. With increasing exposure duration and concentration of phosphogypsum lower growth rate, declined feeding habit, maximum respiration rate and deprived regeneration power were noticed. The highest and lowest growths were $1.39 \mathrm{gm}$ at $0 \%$ and $0.05 \mathrm{gm}$ at $10 \%$, respectively. Maximum feeding rate was 32.65 with a minimum rate $16.20 \mathrm{~g} \mathrm{~g}^{-1}$ live tissue. Respiration rate was highest at $10 \%$ i.e. $0.0578 \mathrm{~g}^{-1}$ live worm tissue $\mathrm{hr}^{-1} \mathrm{~kg}^{-1}$ soil, as most of the energy used to respire to sustain in such diverse condition and $0.575 \mathrm{~g}^{-1}$ live worm tissue $\mathrm{hr}^{-1} \mathrm{~kg}^{-1}$ soil recorded as lowest in $0 \%$. The rate of regeneration was deeply hampered and there was no viable worms left at $8 \%$ and $10 \%$ concentration to assess. Regeneration was only observed at $0 \%$ and $4 \%$.
\end{abstract}

Keywords: growth, feeding, respiration, regeneration, earthworm, concentration

\section{Introduction}

Anthropogenic activity and environmental changes are the major sources which directly affect the integrity of terrestrial ecosystems. Industrial activities, waste disposal and agricultural practices are sources of soil pollution. Soils are complex associations containing living organisms, mineral particles and organic matter. The clay fractions of the minerals and the humus of organic matter are colloids of a very small size with a large surface area to volume ratios, and consequently with a high binding capacity to inorganic and organic molecules. The binding of pollutants to soil colloids reduces their mobility and their bioavailability and modulates their biological effects. Deposition of different contaminants on soil through anthropogenic sources are very much prone to alter the basic composition and this might be hazardous to inhabiting organisms. The macrofaunal groups of soil are the integral part of the soil ecosystem and have a significant role in soil fertility and functioning. Earthworms are the one of the macrofaunal inhabitant of the soil and hold the key role in soil formation, alternation and function.

The casts of earthworms boost soil fertility and help various organisms to inhabit the soil and to complete their life cycle. Macro- and micro nutrients and their cycling process solely depend upon earthworms and it has been shown that macronutrients are abundant around earthworm casts and burrows which supports root growth (Edwards and Bater, 1992). Earthworm casts have been found to contain elevated amounts of $\mathrm{NH}$ :, $\mathrm{NO}$; $\mathrm{Mg}, \mathrm{K}$ and $\mathrm{P}$ relative to the surrounding soil (Lunt and Jacobson, 1944; 
Parle, 1963; Gupta and Sakal, 1967; Syers et al., 1979; Syers and Springett, 1984; Tiwari et al., 1989). Earthworms influence the soil structure by forming macropores, which allow oxygen to enter the soil, whereas micropores between the aggregates give a good water-holding capacity (Lavelle, 1988; Willems et al., 1996). In addition to forming macropores and increasing water infiltration, earthworms have been shown to increase soil the aggregate stability ( $\mathrm{Li}$ and Ghodrati, 1995) and the water-holding capacity (Stockdill, 1982).

Generally organisms are known to avoid areas polluted with contaminants above tolerable levels (Amorim et al., 2005; Fenoglio et al., 2007). Earthworms serve as indicators of soil status such as the level of pollutants e.g. agrochemicals, heavy metals, toxic substances, industrial effluents and human-induced activities e.g. landmanagement practices and forest degradation (Radha and Natchimuthu, 2010). Any changes in soil properties have great impact on earthworms and hence they serve as indicator organisms for ecotoxicological studies (OECD, 1984).

The human impact on the environment can be scaled by the measurements of heavy metals in the soil, in plants and in animals because metal pollution adversely affects the density and diversity of biotic communities including humans (Bengtsson et al., 1981; Mountouris et al., 2002). the abundance and distribution of earthworm species (Pontoscolex corethrurus, Perionex excavatus, Dichogaster modigliani and Polypheretima elongate) (Ching et al., 2006), is primarily based on soil the type, soil moisture, texture and the soil constituent. Usually, the abundance and distribution of earthworms in undisturbed soil are greater than those, that soils that have been cultivated, burnt or undergone various crop practices like the use of fertilizers, fallowing etc. Some researchers have focused on the role of earthworm species in their tolerance and absorption of metals, petroleum hydrocarbons and polynuclear aromatic hydrocarbons (PAHs) (Zachary and Reid, 2008; Owojori et al., 2009).

Generally, the potential hazards of various environmental toxicants to soil invertebrates are assessed by bioassays with the keystone species - earthworm. Earthworms are one of the first receptors affected by soil contamination. They are more susceptible to metal pollution than any other groups of soil invertebrates and toxicity data on earthworms are important in determining "Safe levels" for metals and other contaminants in soil.

Heavy metals have been shown to cause lysosomal membrane instability, changes in gene expression, oxidative stress (Spurgeon et al., 2004a; Berthelot et al., 2008; van Gestel et al., 2009), reduced growth (Spurgeon et al., 1994), slower sexual development (Spurgeon and Hopkin, 1996; Spurgeon et al., 2004b), depleted cocoon production, hatchability (Reinecke et al., 2001; Davies et al., 2003; Spurgeon et al., 2004a) and juvenile viability (Bengtsson et al., 1986; van Gestel et al., 1992), increased mortality (Neuhauser et al., 1985; Spurgeon et al., 1994; Davies et al., 2003) and also they affect the population size, abundance and species diversity of earthworms (Spurgeon et al., 2005).

Earthworms, especially the compost worm Eisenia fetida, are model organisms for assessing the effects of various chemicals on terrestrial invertebrates (Spurgeon et al., 2003; Nahmani et al., 2007). Eisenia fetida (andrei), which is a manure species living in organic matter-rich substratum is recommended by the international guidelines (OECD, 1984; ISO, 1998) as a test species and has been mainly used in genotoxicity studies. It has a short life cycle, hatching from cocoons in 3 to 4 weeks, and reaching maturity in seven to eight weeks. It is a prolific species and its rearing in laboratory is 
simple. It is a representative component of the terrestrial fauna, but is mostly used as a compost worm because of its great potential towards decomposing waste. It is an epigeic species and is sensitivity to soil pollutants compared to other field earthworms.

Leachate is a liquid formed from the percolation of rain water through the disposed wastes. The dissolution of contaminants such as heavy metals in the leachate can pose serious pollution problems. Species richness may be reduced due to metal pollution (Nahmani et al., 2003) and this indirectly alters species interaction (Grzes, 2009). From ecotoxicity point of view, earthworms are likely to be sensitive to tillage, inputs of organic matter and the application of chemicals (Edwards et al., 1995 and Smith et al., 2008). Due to their beneficial role in terrestrial ecosystems, earthworms are often used as an indicator species in ecotoxicological evaluation (Abdul Rida and Bouche, 1995). Previously few attempts have been made to study the effect of industrial discharge on earthworms (Goats and Edwards, 1982; Mishra and Sahu, 1989, 1997; Callahan et al., 1991).

Heavy metal can be defined as any metal with a specific gravity higher than 4.00 and which is toxic and poisonous even at a low concentration (Agbaire and Emoyan, 2012). Heavy metal concentrations in the soil are associated with biological and geochemical activities and are influenced by anthropogenic activities (Agbaire and Emoyan, 2012). Heavy metals are considered serious pollutants because they are toxic and non-degradable (Agbaire and Emoyan, 2012). The accumulation of heavy metals in the soil poses many risks to humans and the ecosystems (Odoh et al., 2011). Most importantly pollution by heavy metals in terrestrial ecosystems is a serious environmental concern due to their non-biodegradability and tendency to accumulate in plants and animal tissues (Otitoloju et al., 2009).

As a by-product phosphogypsum is produced in phosphoric acid plants. Phosphogypsum is generated through a filtration process in phosphoric acid plants where insoluble gypsum is separated from the product i.e. phosphoric acid as efficiently as possible. About 4.5 -5 tons of phosphogypsum as by-product is being generated per ton of phosphoric acid recovered. Phosphogypsum generation in India is about 11 million tons per annum and primarily consists of calcium sulphate dihydrate with small amounts of silica, usually as quartz and un-reacted phosphate rock, radioactive material (like radium, uranium) and heavy metals namely arsenic, cadmium, chromium, mercury, nickel, lead and zinc (HAZWAMS/2012-2013). There was very considerable volume of work and research regarding the positive roles of earthworms in agroecosystems, environmental monitoring and sustainability (Dada et al., 2013) but the concern here is to evaluate the influence of phosphogypsum over various physiological parameters of Eisenia fetida under laboratory conditions.

\section{Review of literature}

Lee et al. (2009) determined the effect of alkalized phosphogypsum on soil chemical and biological properties. Their study came into the conclusion that by mixing alkalizing phosphogypsum with an alkaline material such as $\mathrm{Ca}(\mathrm{OH}) 2$ can turn it into a useful material for agricultural utilization. Pure phosphogypsum could damage the soil biological properties.

Mishra et al. (2011) assessed the impact of phosphogypsum amendment on soil physic-chemical properties, microbial load and enzyme activities. They carried out 
their experiment with $0,5,10$ and $15 \%$ of Phosphogypsum to track the impact and found that the optimal results were recorded in $10 \%$. The experiment summarized with a conclusion that Phosphogypsum amendment will be fruitful at a particular range and can be fatal for the microbial and soil enzyme activities if it exceeded its threshold range.

Chen et al. (2014) investigated the effects of gypsum on trace metals in soil and earthworms. For the study they used FGD (Flue Gas Desulfurization) gypsum which was produced by the removal of SO2 from flue gas streams. The application rates of gypsum ranged from $2.2 \mathrm{Mg} \mathrm{ha}^{-1}$ to $20 \mathrm{Mg} \mathrm{ha}^{-1}$. These rates were 2 to 10 times higher than typically recommended. It was observed that the earthworm numbers and biomass were decreased significantly and with the higher rates of gypsum application was found to be hazardous to earthworms and soil integrity.

Rakhimova et al. (2017) evaluated the impact of coal ash and phosphogypsum on soil fertility of Chernozem soils of north Kazakhstan. Soil samples were collected (three times a year) and the initial content of humus, $\mathrm{pH}$, plant nutrient elements and heavy metal content of the soil were tested in laboratory and recorded. The application of Phosphogypsym and coal ashes for fertilization of the soils influenced the growth of soil nutrient elements such as nitrogen, phosphorous, copper and zinc. It also impacted the on neutralization of the soil environment and further investigation is needed to find out actual content of heavy metals $(\mathrm{Cu}, \mathrm{Zn}, \mathrm{Cd}$ and $\mathrm{Pb})$.

\section{Materials and methods}

\section{Material}

\section{Phosphogypsum}

Phosphogypsum was collected from Paradeep Phosphate Limited (PPL), Paradeep, Jgatsinghpur, Odisha, India.

\section{Earthworm used}

Eisenia fetida used as experimental organisms. For regeneration adult earthworms with prominent clitellum were used.

\section{Soil}

Soil was sieved using $2 \mathrm{~mm}$ sieve and packets were made containing $0 \mathrm{~g} \%, 4 \mathrm{~g} \%$, $8 \mathrm{~g} \%$ and $10 \mathrm{~g} \%$ gypsum with $25 \mathrm{~g} \%$ water.

\section{Method}

$500 \mathrm{gm} 2 \mathrm{~mm}$ sieved, air dried soil was taken in polythene packets with moisture maintained at $25 \mathrm{~g} \%$ by addition of distilled water in all packets. The control consisted of $500 \mathrm{~g}$ soil only and PG was added to soil in experimental sets i.e. $4 \%, 8 \%$ and $10 \%$. Ten replicates of each concentration were taken for each parameter (growth, feeding, respiration and regeneration). After moisture addition the packets were left for five days for stabilization. Culture was maintained with $25 \mathrm{~g} \%$ moisture and $25{ }^{\circ} \mathrm{C}$ temperature (Initially we went for $25 \mathrm{~g} \%, 50 \mathrm{~g} \%$ and $75 \mathrm{~g} \%$ concentration of phosphogypsum with $25 \mathrm{~g} \%$ water for the experiment but it was found that worms unable to tolerate such high amount of phosphogypsum percentage and found dead). 


\section{Experimental set up for growth}

After five days of moisture addition and stabilization of soil, up to $1.70 \mathrm{~g}$ of earthworms were inoculated to each packet. Weight of earthworms in each packet was determined and change in weight over initial weight was observed after on $10^{\text {th }}$, 20th and 30th days. Percentage change in weight of earthworms over zero day culture was estimated.

\section{Experimental set up for feeding}

$2.5 \mathrm{~g}$ of earthworms were inoculated to each packet and estimation of stable aggregates was done at an interval of 10 days by sieving culture sets with water. Carbon content of stable aggregate formed was estimated by Walkley and Black titration method (Walkley and Black, 1934). Then the amount of carbon was converted to energy according to available standard values energy conversion for carbon is $41.44 \mathrm{~kJ} \mathrm{~g}^{-1}$ dry wt. (Remmert, 1980).

\section{Experimental set up for respiration}

Out of 10 replica of each concentration, 5 were maintained without earthworms which accounted for microbial respiration. To each packet, an average of $1.5 \mathrm{~g}$ of earthworms were added. The respiratory metabolism was estimated on 10th, 20th and 30th day by Alkali Absorption Method (Witkamp, 1966). Carbon dioxide evolution was measured and expressed as $\mathrm{mg}$ of $\mathrm{CO}_{2} . \mathrm{g}^{-1}$ live worm tissue $\mathrm{hr}^{1} \mathrm{~kg}^{1}$ soil.

\section{Experimental set up for regeneration}

For regeneration, the guts of the matured earthworm were cleaned and about $50 \%$ of post clitellar region was cut with sharp blade. Five earthworms were inoculated into each packet after amputation. Thus twenty five earthworms each were cultured in control, $4 \%, 8 \%$ and $10 \%$ of phosphogypsum. The amputed earthworms could not survive in $8 \%$ and $10 \%$ phosphogypsum. So the regeneration experiment was performed with $4 \%$ PG only.

\section{Statistical analysis}

Statistical analysis were performed to infer the results (Microsoft excel version 2007). For growth, feeding and respiration, ANOVA test was performed. T-test was performed for regeneration. Comparisons of values were made and values at $p \leq 0.01$ are said to be significant.

\section{Results}

\section{Growth}

Table 1 and Figure 1 indicate the changes in the growth i.e. changes in weight pattern of Eisenia fetida earthworm under the impact of phosphogypsum in laboratory cultures. In the first phase of estimation (initial 10 days), a positive increase of about $1.53 \%$ in weight in control set ups was observed in comparison to experimental set ups. On exposure to $4 \%, 8 \%$, and $10 \%$ phosphogypsum, there was significant decrease (at 0.01 level) of about $23.07 \%, 23.07 \%$ and $75 \%$ respectively over zero day. At 20 days, 
the weight percentage reached up to 5.03 over zero day in control but a continuous decrease in weight by $33.84 \%, 68.46 \%$ and $93.84 \%$ was observed when exposed to $4 \%$, $8 \%$ and $10 \%$ of phosphogypsum. After the end of final phase (last 10 days), $96.40 \%$ decrease in weight over initial weight at $10 \%$ phosphogypsum. In at $4 \%$ and $8 \%$, weight was decreased by 30.93 and $74.82 \%$ over initial weight respectively. But in Control sets, there was a remarkable growth noticed (21.53\%). Analysis of variance showed significant impact of phosphogypsum treatment on earthworm weight at 0.01 level of significance.

Table 1. Weight of Eisenia fetida earthworm under impact of phosphogypsum in laboratory culture

\begin{tabular}{c|c|c|c|c|c}
\hline \multirow{2}{*}{ Culture in days } & \multirow{2}{*}{ Parameter analysed } & \multicolumn{4}{|c}{ Conc. of phosphogypsum in \% } \\
\cline { 3 - 6 } & & $\mathbf{0}$ & $\mathbf{4}$ & $\mathbf{8}$ & $\mathbf{1 0}$ \\
\hline \multirow{2}{*}{0} & Weight \% change over & 1.01 & 1.03 & 1.05 & 1.02 \\
& ' 0 ' day & 0 & 0 & 0 & 0 \\
\hline \multirow{2}{*}{10} & Weight \% change over & 1.04 & 0.8 & 0.8 & 0.26 \\
& '0' day & +1.53 & -23.07 & -23.07 & -75.0 \\
\hline \multirow{2}{*}{20} & Weight \% change over & 1.3 & 0.86 & 0.41 & 0.08 \\
& '0' day & +5.3 & -33.84 & -68.46 & -93.84 \\
\hline \multirow{2}{*}{30} & Weight \% change over & 1.39 & 0.96 & 0.35 & 0.05 \\
& '0' day & +21.53 & -30.93 & -74.82 & -96.40 \\
\hline
\end{tabular}

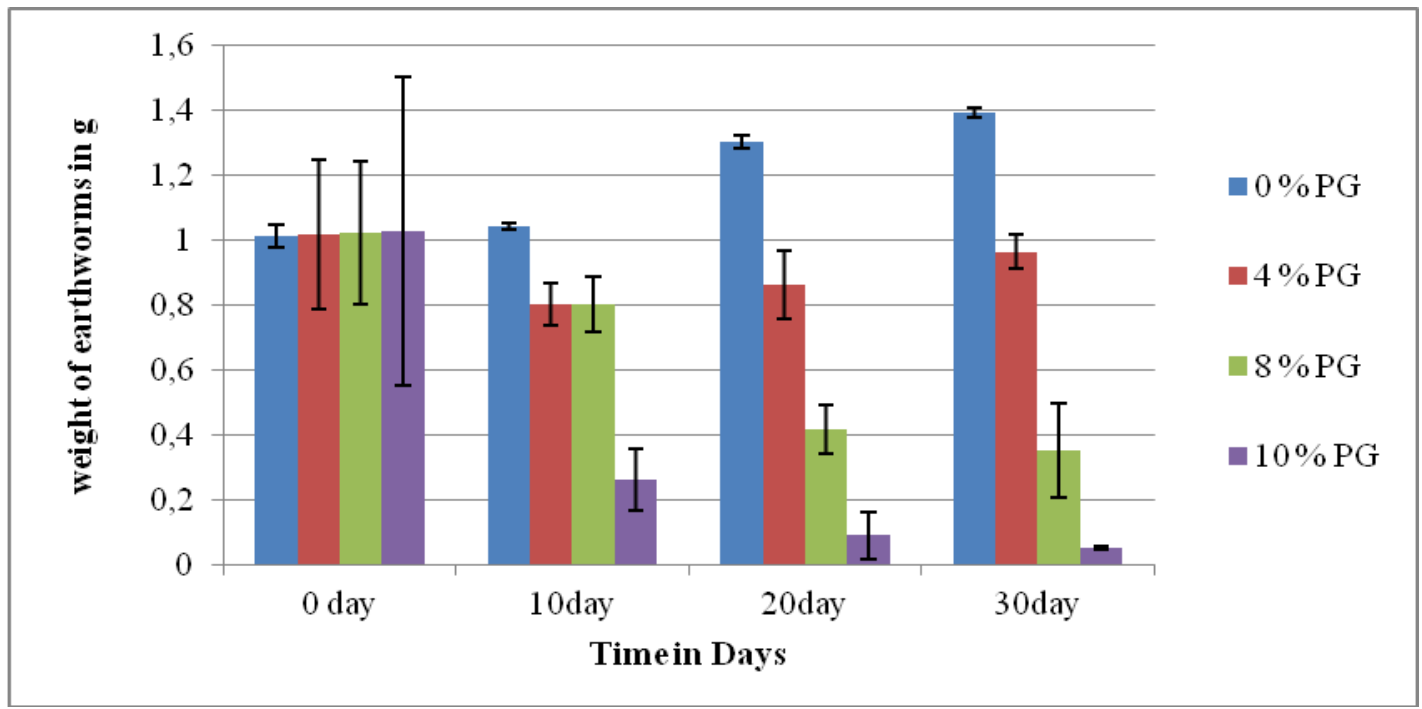

Figure 1. Change in weight of Eisenia fetida earthworm under the impact of phosphogypsum in laboratory culture. (Mean \pm standard deviation)

\section{Feeding}

After 10 days of exposure to $0,4,8,10 \%$ of phosphogypsum, the weight of stable aggregates formed was 12.67, 11.72, 12.40 and $9.42 \mathrm{~g} \mathrm{~g}^{-1}$ live tissue (Fig. 2; Table 2) and a visible decrease of about $0.009 \%, 97.66 \%$ and $99.20 \%$ in stable aggregate formation as comparison to zero day in 4, 8 and $10 \%$ of phosphogypsum respectively (Fig. 3). On completion of 30 days there was decrease of about $99.7 \%, 99.8 \%$ and 
$99.93 \%$ respectively was observed (Table 2). When it comes to the matter of carbon content of stable aggregate formed by the earthworms, a consistent and significant decline was noticed by the increase of concentration dose and exposure duration (Fig. 4). Highest energy content of stable aggregate formed was $784.74 \mathrm{~kJ} \mathrm{~kg}^{-1}$ soil g$^{-1}$ live tissue at $0 \%$ and lowest was $349.09 \mathrm{~kJ} \mathrm{~kg}^{-1}$ soil, $\mathrm{g}^{-1}$ live tissue at $10 \%$ on 30 th day. A remarkable significance difference noticed in stable aggregate formed at the end of 30 days in comparison to 10th day. After 30 days at $0 \%$, the weight of stable aggregate formed by the earthworms was $32.65 \mathrm{~g} \mathrm{~g}^{-1}$ live tissue which was much higher when it compared to 4,8 and $10 \%$ (22.45, 18.16 and $16.20 \mathrm{~g} \mathrm{~g}^{-1}$ live tissue respectively). Analysis of variance showed significant decrease in the stable aggregate formation by the worms (at 0.01 level of significance) on application of phosphogypsum. Significant decrease in energy content of stable aggregate was also found at 0.01 level of significance.

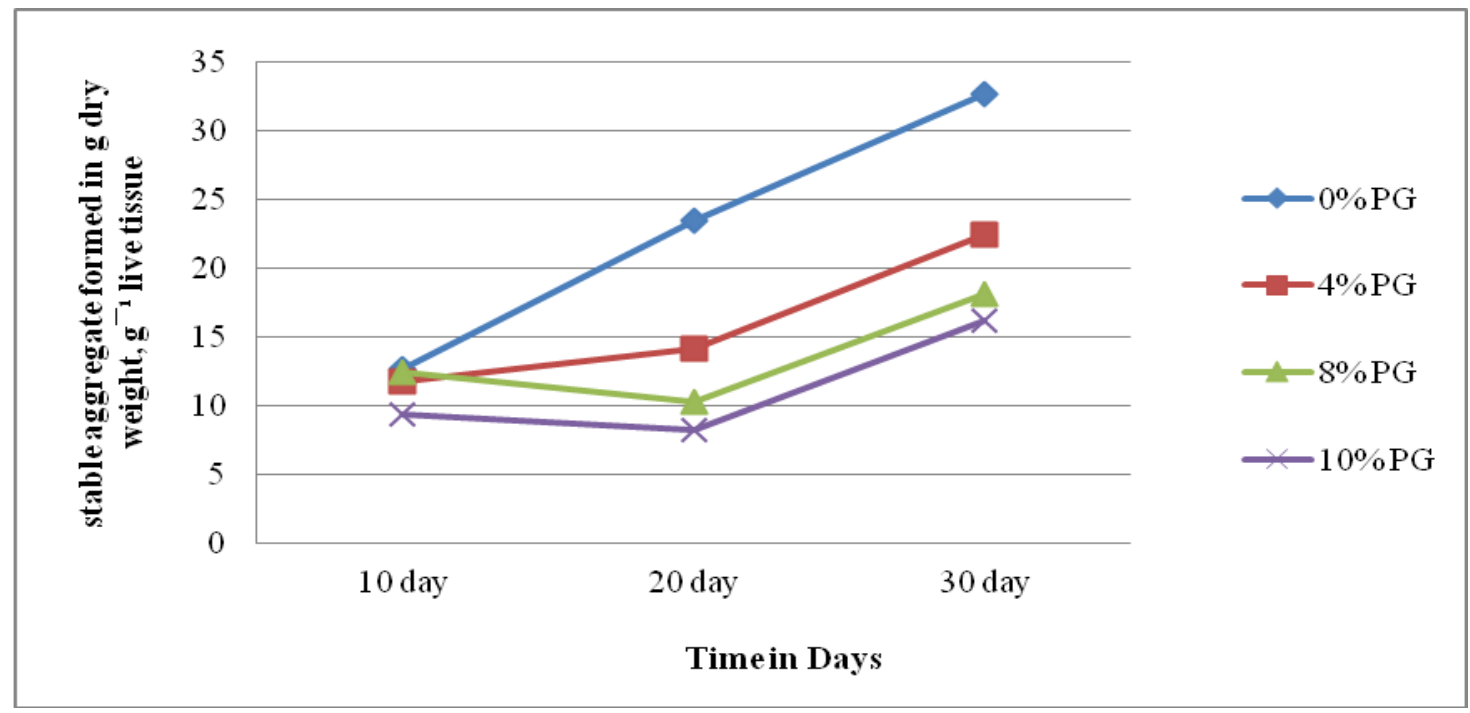

Figure 2. Stable aggregate formed by Earthworm Eisenia fetida under the impact of phosphogypsum in laboratory condition

Table 2. Stable aggregate formed by Eisenia fetida under the impact of phosphogypsum

\begin{tabular}{|c|c|c|c|c|c|}
\hline \multirow{2}{*}{ Culture time in days } & \multirow{2}{*}{ Parameters analysed } & \multicolumn{4}{|c|}{$\begin{array}{c}\text { Concentration of phosphogypsum in } \\
\text { percentage }\end{array}$} \\
\hline & & $\mathbf{0}$ & 4 & 8 & 10 \\
\hline \multirow{3}{*}{10} & Weight of stable aggregate & 12.67 & 11.72 & 12.40 & 9.42 \\
\hline & $\%$ change over " 0 " percent & 0 & -0.009 & -97.66 & -99.20 \\
\hline & Energy content & 283.52 & 237.98 & 226.09 & 160.04 \\
\hline \multirow{3}{*}{20} & Weight stable aggregate & 23.40 & 14.16 & 10.32 & 8.25 \\
\hline & $\%$ change over " 0 " percent & 0 & -99.12 & -99.57 & -97.81 \\
\hline & Energy content & 552.72 & 332.73 & 209.55 & 164.44 \\
\hline \multirow{3}{*}{30} & Weight stable aggregate & 32.65 & 22.45 & 18.16 & 16.20 \\
\hline & $\%$ change over " 0 " percent & 0 & -99.7 & -99.8 & -99.93 \\
\hline & Energy content & 784.74 & 530.28 & 414.65 & 349.09 \\
\hline
\end{tabular}

Weight: $g$ dry weight stable aggregates, $\mathrm{g}^{-1}$ live tissue $\%$ change: gain or loss

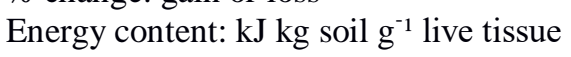




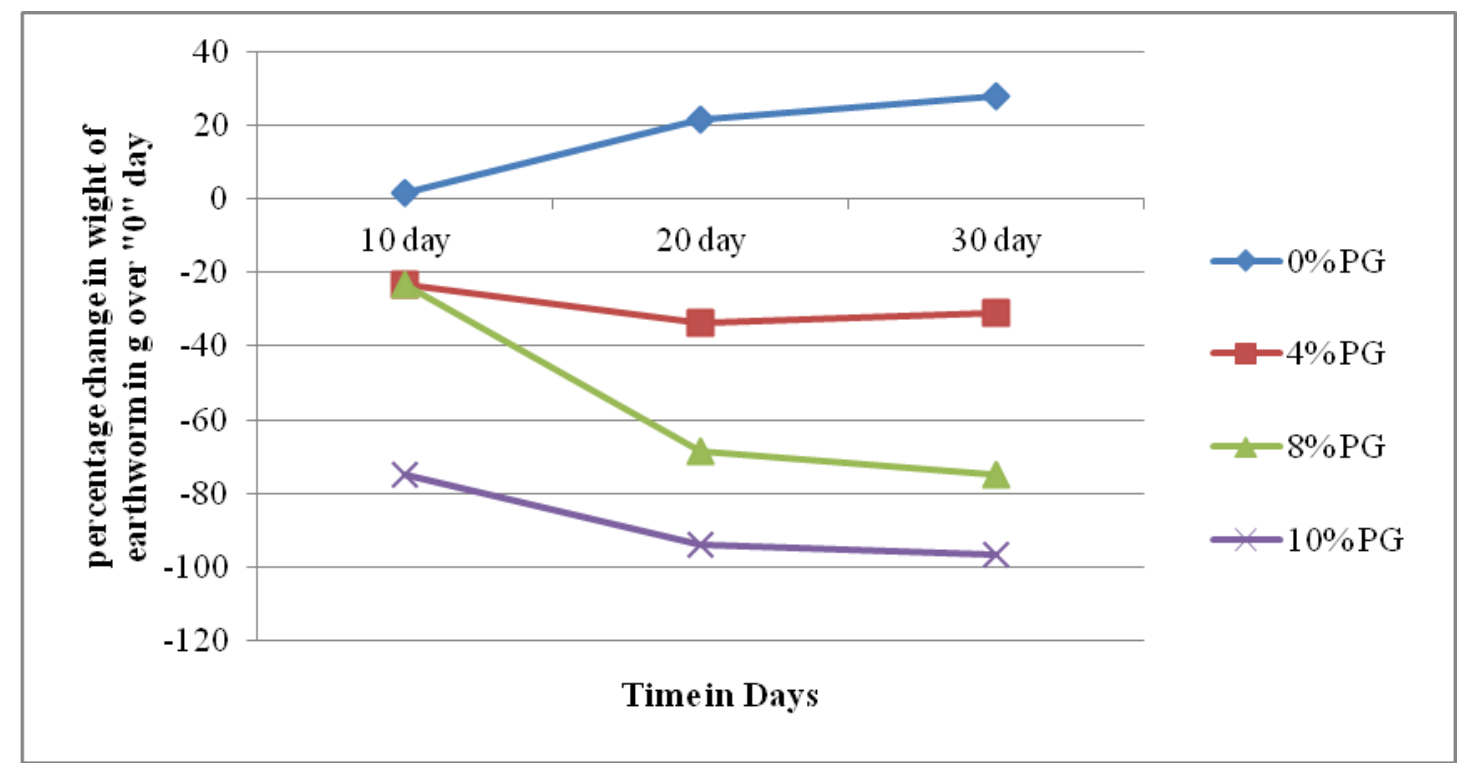

Figure 3. Percentage change in weight of earthworm Eisenia fetida under the impact of phosphogypsum in laboratory cultures

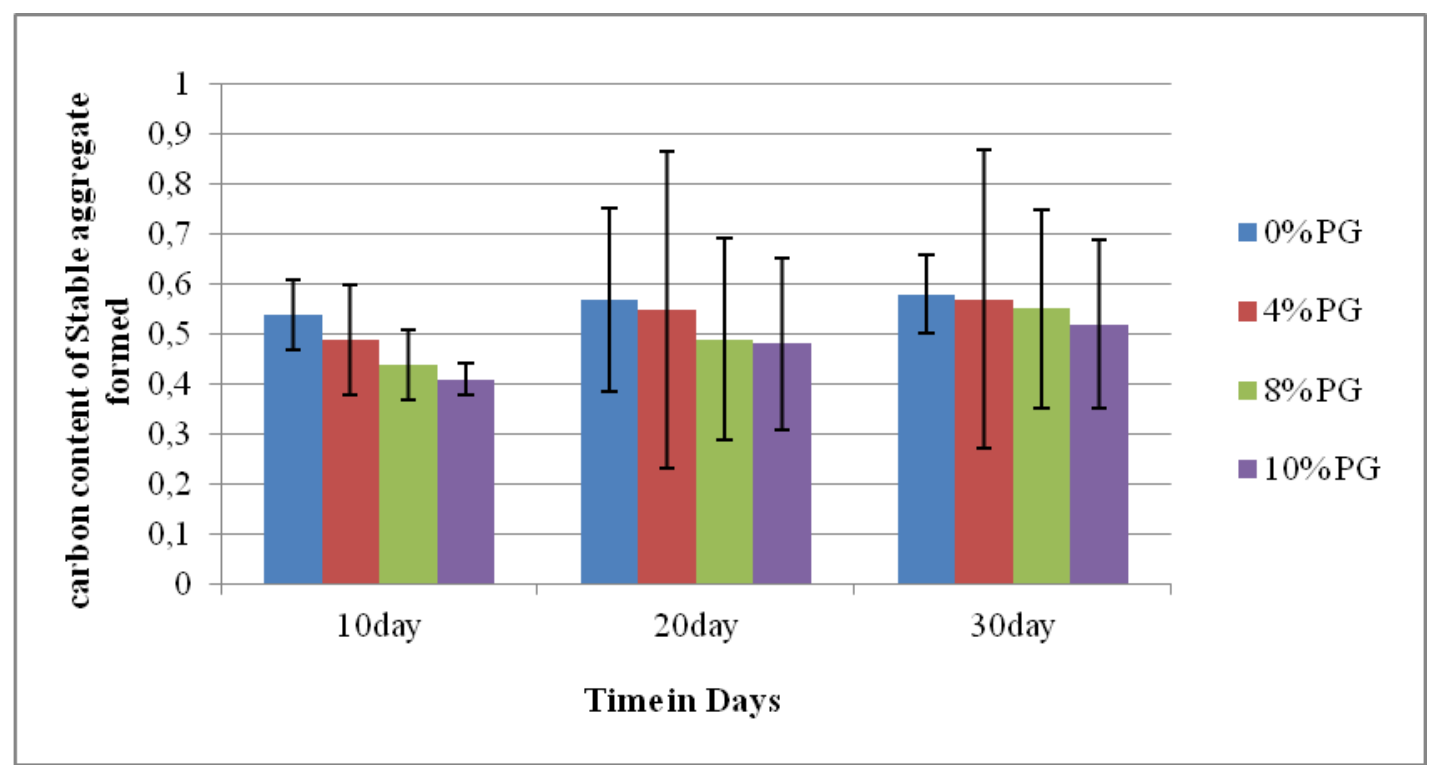

Figure 4. Carbon content of stable aggregate formed by earthworm Eisenia fetida under the impact of phosphogypsum in laboratory cultures. (Mean \pm standard deviation)

\section{Respiration}

The rate of respiration was found to increase with duration and treatment. After 10 days of exposure the rate of respiration was found to be $0.0564,0.0565,0.0567$ and $0.0568 \mathrm{mg}$ of $\mathrm{CO}_{2}$ evolved, $\mathrm{g}^{-1}$ live worm tissue $\mathrm{hr}^{-1} \mathrm{~kg}^{-1}$ soil at $0 \%, 4 \%, 8 \%$ and $10 \%$ of phophogypsum, respectively (Fig. 5; Table 3). At the end of the last phase (30 days), there was increase of about $0.17 \%, 0.34 \%$ and $0.52 \%$ in rate of respiration on exposure to $4 \%, 8 \%$ and $10 \%$ phosphogypsum over control respectively. The $\mathrm{mg}$ of $\mathrm{CO}_{2}$ i.e. evolved, $\mathrm{g}^{-1}$ live tissue $\mathrm{hr}^{-1} \mathrm{~kg}^{-1}$ soil increased from lower concentrations to higher 
concentrations of phosphogypsum as the days increased. Analysis of variance showed significant increase in respiratory metabolism of earthworm at 0.01 level of significance under the impact of phosphogypsum.

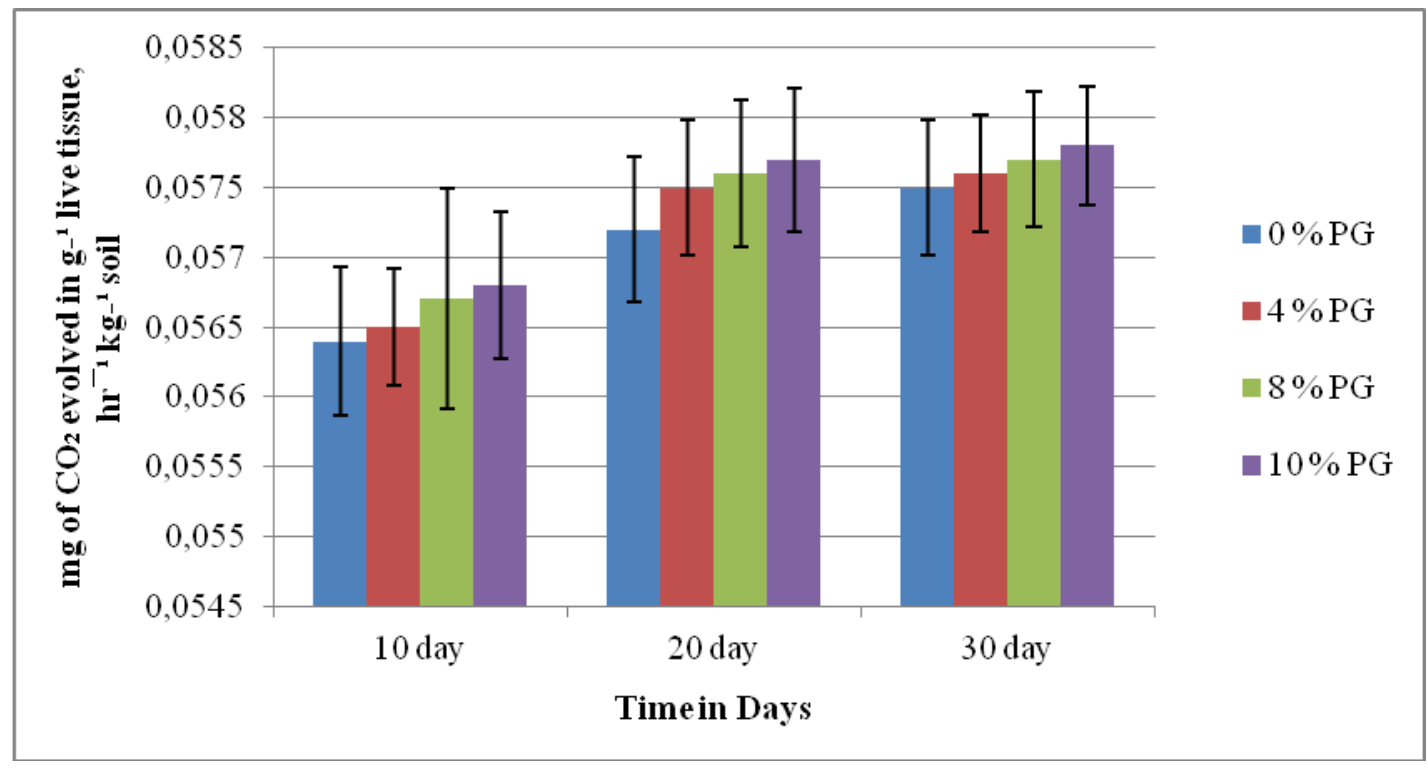

Figure 5. Respiratory metabolic rate of earthworm Eisenia fetida under the impact of phosphogypsum. (Mean \pm standard deviation)

Table 3. Respiratory metabolic rate of Eisenia fetida earthworm under the impact of phosphogypsum

\begin{tabular}{c|c|c|c|c}
\hline \multirow{2}{*}{$\begin{array}{c}\text { Culture time } \\
\text { (in days) }\end{array}$} & \multicolumn{4}{|c}{$\begin{array}{c}\text { Rate of respiration (mg of } \mathrm{CO}_{2} \text { evolved, } \mathbf{g}^{-1} \text { live worm tissue } \mathbf{~ h r}^{-\mathbf{1}} \mathbf{k g}^{-\mathbf{1}} \text { soil ) at } \\
\text { different concentrations of phosphogypsum in percentage }\end{array}$} \\
\cline { 2 - 5 } & $\mathbf{0 \%}$ & $\mathbf{4 \%}$ & $\mathbf{8 \%}$ & $\mathbf{1 0 \%}$ \\
\hline $0-10$ & $0.0564 \pm 0.000516$ & $0.0565 \pm 0.000527$ & $0.0567 \pm 0.000527$ & $0.0568 \pm 0.000422$ \\
$10-20$ & $0.0572 \pm 0.000789$ & $0.0575 \pm 0.000527$ & $0.0576 \pm 0.000516$ & $0.0577 \pm 0.000483$ \\
$20-30$ & $0.0575 \pm 0.000527$ & $0.0576 \pm 0.000516$ & $0.0577 \pm 0.000483$ & $0.0578 \pm 0.000422$ \\
\hline
\end{tabular}

Mean \pm standard deviation

\section{Regeneration}

The amputated earthworms could not survive beyond two days in $8 \%$ and $10 \%$ phosphogypsum. So the experiment was continued with control and $4 \%$ phosphogypsum. On completion of 10 days of exposure to $0 \%$ and $4 \%$ of phosphogypsum, the percentage increase in regenerated segments was found to be $6.28 \%$ and $2.68 \%$ respectively (Figs. 6 and Table 4). After 20 days of exposure to $0 \%$ and $4 \%$, the percentage of regenerated segments was found to be 10.64 and $5.72 \%$ respectively. At the end of 30 days, the percentage increase in regenerated segments was found to be $13.4 \%$ in $0 \%$ and $8.4 \%$ in $4 \%$. The regenerated parts of the worm grown in $4 \%$ phosphogypsum can be marked in the Fig. 7 after the completion of 30 days. T-test reveals that impact of phosphogypsum has a significant effect on Eisenia fetida at 0.01 level of significance. 


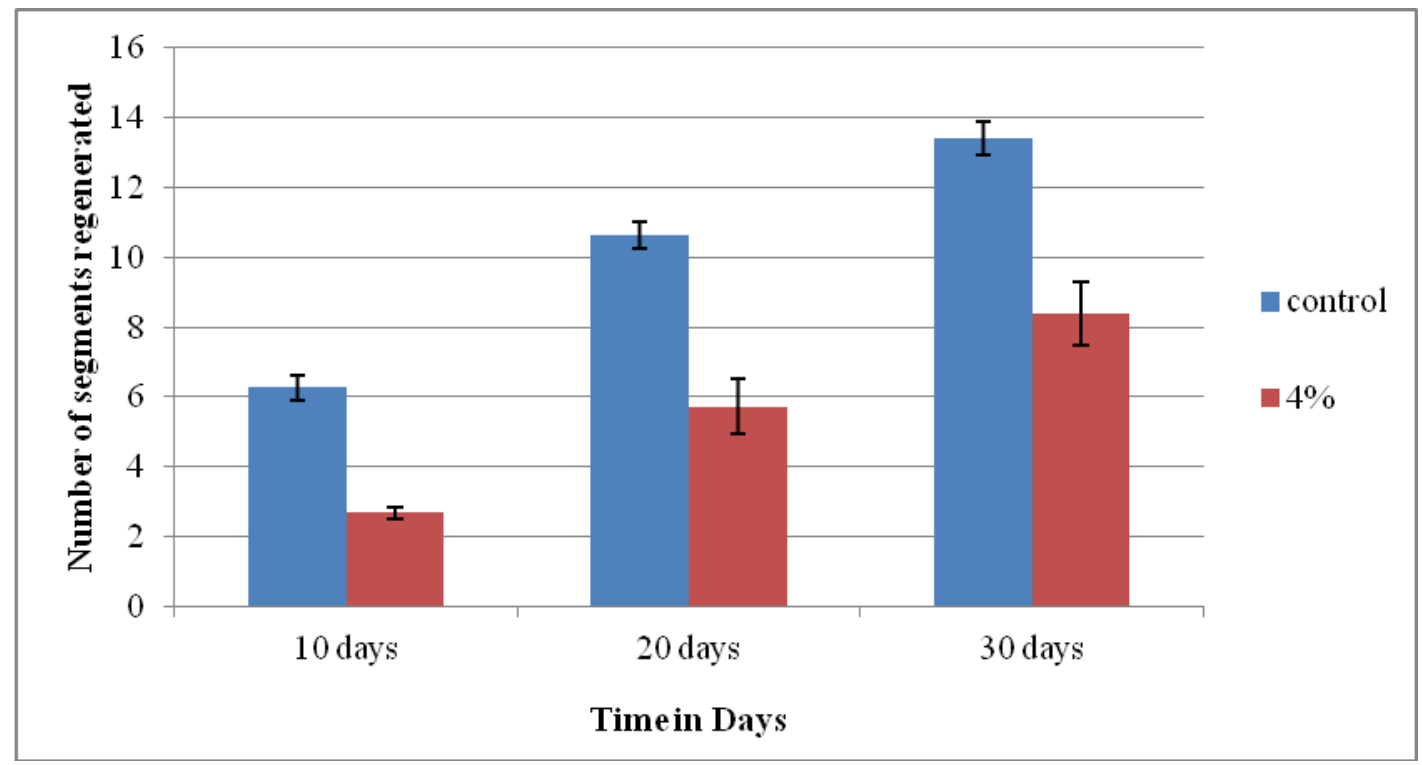

Figure 6. Percentage change in regeneration of earthworm Eisenia fetida under the impact of phosphogypsum in laboratory culture. (Mean \pm standard deviation)

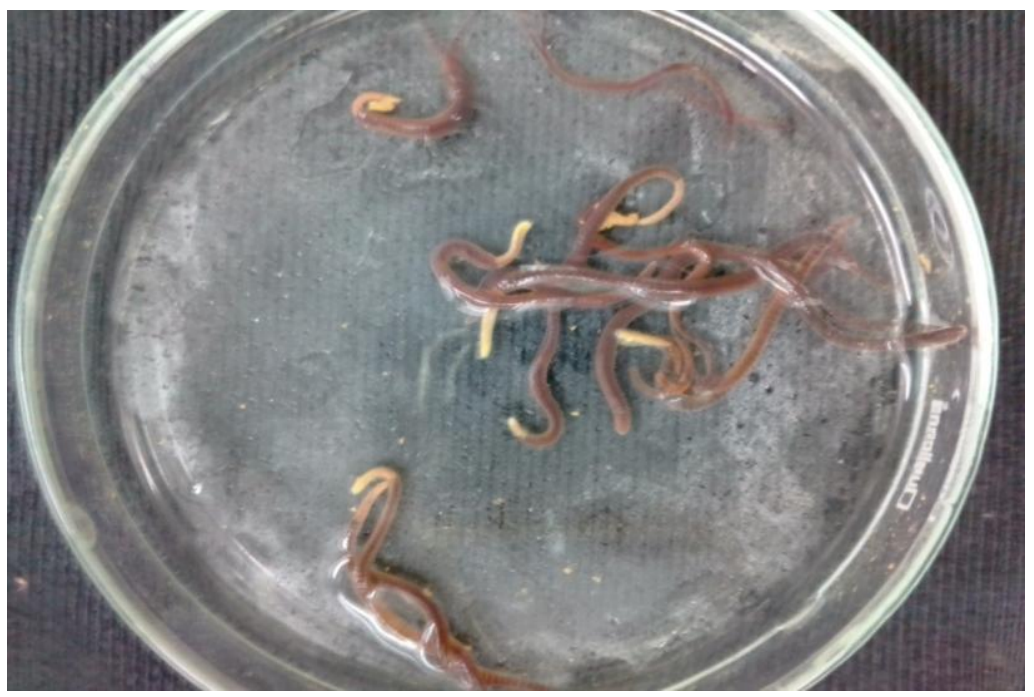

Figure 7. Regenerated segments of earthworm Eisenia fetida at 4\% phosphogypsum

Table 4. Regeneration of Eisenia fetida earthworm under the impact of phosphogypsum in laboratory culture

\begin{tabular}{c|c|c|c}
\hline \multirow{2}{*}{ Culture in days } & \multirow{2}{*}{ Parameters analysed } & \multicolumn{2}{|c}{ Conc. of PG in g \% } \\
\cline { 3 - 4 } & & Control & $\mathbf{4}$ \\
\hline \multirow{2}{*}{10} & Total no. of segments regenerated & 6.28 & 2.68 \\
& \%age change over control & 0.0 & 57.32 \\
\hline \multirow{2}{*}{20} & Total no. of segments regenerated & 10.64 & 5.72 \\
& \%age change over control & 0.0 & 46.24 \\
\hline \multirow{2}{*}{30} & Total no. of segments regenerated & 13.4 & 8.4 \\
& \%age change over control & 0.0 & 37.31 \\
\hline
\end{tabular}




\section{Discussion}

Earthworms ingest organic matter of the soil particle and excrete this in the form of casts, which get deposited on the soil surface and this cast acts as a natural fertiliser for the soil and boosts the soil fertility. Loss of fertility is directly proportional to stable aggregate formed by earthworms. Heavy metallic factor present in the soil directly affects the various physiological activities of E. fetida. Majority of heavy metals are toxic to living organisms when retained in the soil and interfere with the biochemical processes and alter the ecological balance (Nwuche and Ugoji, 2008). These heavy metals do not biodegrade rather they bioaccumulate and this may have adverse effects on the biodiversity of the area if the organisms do not develop a mechanism of adaptation to it. Nickel and lead accumulated significantly in worm bodies during the 3weeks exposure whereas zinc accumulation was efficiently regulated. Nevertheless zinc exposure significantly inhibited the weight gain. Inhibition of weight gain in zincexposed worms may be putatively explained by the high energetic costs of efficient zinc regulation (Podolak et al., 2011).

In many other case studies, D. veneta (Kwadrans et al., 2008) and Aporrectodea caliginosa (Dutkiewicz et al., 2009) were maintained for 4 and 8 weeks, respectively, in soil samples soaked with $\mathrm{Cd}, \mathrm{Cu}, \mathrm{Pb}$, or Ni chlorides. Body weights of D. veneta were unaffected by 4-weeks metal exposure. In a study by Spurgeon et al. (1992), control worms and those on the lowest concentration of metals had slightly increased in weight after 1 week. However, in subsequent weeks their weight declined. Malecki et al. (1982) tested the effect of $\mathrm{Cd}, \mathrm{Cu}, \mathrm{Pb}, \mathrm{Ni}$ and $\mathrm{Zn}$ on the physiological activity of Eisenia fetida in laboratory cultures. They concluded that cadmium was the most toxic metal, as significant decreases in growth noticed. Here it is important to mention that Cadmium is one of the heavy metal present in the phosphogypsum beyond the recommended range. It was observed (Khalil, 2013) that earthworms Allolobophora caliginosa feed less and Pheretima hawayana escaped into their burrows when exposed to arsenate. Miguel et al. (2012) revealed in a study that weight and mortality of the worms were significantly affected by high levels of heavy metals.

Metal exposure can imbalance the host-bacteria relationship, as evidenced in $D$. veneta after 3-days exposure to filter paper soaked with water (controls) or metal ( $\mathrm{Zn}$, $\mathrm{Cu}$, or $\mathrm{Cd}$ ) chlorides (Podolak et al., 2011). It may assumed that effects of metal exposure on immunity are rather associated with the disrupted balance between the worm immune system and microbial impact from surrounding metal-polluted soil (Salice and Roesijadi, 2002; Wieczorek-Olchawa et al., 2003; Olchawa et al., 2006). Various results indicated that earthworm activity increases the mobility and bioavailability of heavy metals in soil (Wen et al., 2004; Sizmur and Hodson, 2009). But the matter is how far and how much worms can accumulate and able to rotate the mobility of heavy metals. Although concentrated heavy metals in the earthworm's body demonstrate the ability of $E$. fetida to accumulate the heavy metals in their body still it needs to reveal the limit or range which is non-deleterious.

Fordsmand et al. (1998) investigated the toxic effects of nickel on survival, growth, and reproduction of Eisenia veneta for 4 weeks of exposure to a nickel chloride spiked loamy sand soil. Nickel caused a significant toxic effect on E. veneta at soil concentrations above $85 \mathrm{mg} \mathrm{Ni} / \mathrm{kg}$. Survival of adults was only reduced at concentrations above $245 \mathrm{mg} \mathrm{Ni} / \mathrm{kg}$, while adult and cocoon wet weight were not affected by soil nickel concentrations up to $700 \mathrm{mg} \mathrm{Ni} / \mathrm{kg}$. The results of our study are in close agreement with Ma (1983), Neuhauser et al. (1985), Bengtsson et al. (1986), 
Gestel and Dis (1988), Gestel et al. (1989, 1991, 1992). The results of the present study clearly correlate with the work of Zaltauskaite (2010) who reported that E. fetida exposed to different concentrations of lead in the soil tended to lose more weight than those in control.

Single metal such as $\mathrm{Cu}$ can affect the physiology and growth of E. fetida may hampered due to increased tissue concentration of $\mathrm{Cu}$., while the cocoon hatchability and number of juveniles increased as the tissue $\mathrm{Cu}$ concentration increased (Leduc et al., 2008). So it was a combine impact of heavy metals which might be more hazardous and has more pronounced toxicity than the individual metals (Olaniya et al., 1991). In some situations E. fetida can allocate more energy to growth than reproduction, delaying other physiological development (Leduc et al., 2008). A combination of As, $\mathrm{Cr}$ and $\mathrm{Cu}$ can impair growth, affect reproduction and cause death also (Leduc et al., 2008).

Sivakumar and Subbhuraam (2005) evaluated the toxic effects of chromium exposure on E. fetida and found 14-day LC50 values ranging from 1656 to $1902 \mathrm{mg} \mathrm{kg}$ ${ }^{1}$ for $\mathrm{Cr}$ (III) and from 222 to $257 \mathrm{mg} \mathrm{kg}^{-1}$ for $\mathrm{Cr}$ (VI) in ten soils. Cocoon production by E. fetida was reduced by $50 \%$ after exposure to a range between 679 and $1110 \mathrm{mg} \mathrm{Cr}$ (III) $\mathrm{kg}^{-1}$ (Lock and Janssen, 2002b). In a contradictory study Shahmansowri et al. (2005) revealed that though heavy metals such as $\mathrm{Cr}, \mathrm{Cd}, \mathrm{Pb}, \mathrm{Cu}$ and $\mathrm{Zn}$ were bioaccumulated by E. fetida, but a significant reduction of body weight only marked when exposed to higher concentration. Similarly pattern of findings also observed in weight Pheretima guillelmi at high concentration of lead in (Rongquan and Canyang, 2009). Among E. albidus, E. crypticus and E. fetida the most sensitive species towards industrial waste material was E. fetida (Kobeticova et al., 2010). The weight of worms was significantly affected by high levels of heavy metals in the study of Miguel et al. (2012).

Impact can vary due to the different contact times during which the earthworm exposed to contaminants (Haghparast; 2013; Golchin et al., 2013). Concentration of the metals in the body of earthworms can reach the toxic level if the contact time of earthworm is a prolonged duration (Hagparast et al., 2013). Jamshidi and Golchin (2013) also confirmed same. Thus, the potential effects of metals may be overlooked or underestimated in short term experiments (Bengtsson et al., 1986), which may explain the truth that sometimes despite the high levels of metal contamination in the soil, no significant impact may not noticed like Kennett et al. (2002). In a such kind of study, Honsi et al. (2003) reported no effect of heavy metals $(\mathrm{Cu}, \mathrm{Zn}, \mathrm{Cd}$ and $\mathrm{Pb}$ ) on survival of earthworm E. fetida exposed to contaminated soils in Norway despite the fact that the concentrations of metals were high ( $\max \mathrm{Pb}-8750 \mu \mathrm{g} \mathrm{g}^{-1}, \mathrm{Cd}-110 \mu \mathrm{g} \mathrm{g}^{-1}$ soil). Kaur and Hundal (2016) observed a very sound impact of heavy metals in the body weight of earthworms. Berthelot et al. (2008), Matuseviciute et al. (2005) and van Gestel et al. (2009) findings also support our results. Spurgeon and Hopkin (1996) also argued that the worms living in metal polluted soils reached the lower weight or needed more time to reach the maximum weight than in non-polluted sites.

Trace elements added to the soil with gypsum or any soil amendment may be concentrated in food chains as the elements are consumed and passed from one trophic (feeding) level to another level (Duffy and Gulledge, 2011). Garg et al. (2009) found a pattern of heavy metals accumulation in E. fetida after 45 days i.e. $\mathrm{Cr}>\mathrm{Cd}>\mathrm{Pb}>\mathrm{Zn}$ and $\mathrm{Cd}$ had the greatest detrimental effect on cocoon production and matter of concern is these heavy metals are one of the major part of phosphogypsum. 
During their study, Avila et al. (2009) identified that increasing the organic material can reduce the toxicity of heavy metals in the body of earthworms. Irizar et al. (2015) concluded during their study that, if the organic material in the soil is low, earthworms are not able to digest the soil and, as a result, the toxicity of cadmium increases in them, and the mortality and disorder in reproduction rise. Haghparast et al. (2013) showed that organic material is a source of energy for Eisnia Fetida earthworms and increases the percentage of their survival. Avila et al. (2009) showed that adding 5\% of organic matter to soil contaminated with chromium at a concentration of $0.06 \mathrm{mg} / \mathrm{g}$ after 21 days gave no bioremediation, but after 42 days the efficiency of bioremediation $(18.33 \%)$ increased. At the concentration of $0.1 \mathrm{mg} / \mathrm{g}$ the bioremediation efficiency of $30 \%$ after 21 days reached $53 \%$ after 42 days.

Heavy metallic cations are said to be more mobile or dynamic under acid conditions (Alloway, 1996) as the correlation between soil $\mathrm{pH}$ and micronutrients availability has been one of the major aspect of soil (Brady, 1990; Joshi et al., 1983, Sharma et al., 2003; Akinrinde et al., 2005). Although organisms like earthworm can accumulate a high concentration of heavy metals in the body (Shahmansouri et al., 2005; Li et al., 2010; Brewer and Barrett, 1995; Bamgbose et al., 2000) but mineralization of dead earthworms releases accumulated heavy metals back to the soil (Morgan and Morgan, 1988a). The amount of metals accumulated within earthworm tissues is partly dependent on the absolute concentration of metal within a given soil and physiochemical interactions (Ma et al., 1983). When a contaminant is not in equilibrium with the soil, it becomes more bioavailable to living organisms (Davies et al., 2003). Phosphogypsum is one of the industrial waste materials which is acidic in nature and contains various heavy metals. Another major concern here is E. fetida has already been reported as very sensitive species towards industrial waste material exposure by Kobeticova et al. (2010).

Earthworms are well capable of regenerating lost segments, but different species have different regeneration ability. After studying regeneration in different kinds of species for 20 years, Gates (1949) published some of his findings that show for certain species there is a possibility of growing into two intact ones from a bisected specimen. Eisenia fetida with head regeneration, in an anterior direction, possible at each intersegmental level back to and including 23/24, while tails were regenerated at any levels behind $20 / 21$, i.e., two worms may grow from one.

Three potential pathways exist for the removal of chemicals from tissues; elements can be regulated by excretion from the body, bound within the matrix of inorganic granules and attached to proteins or other ligands (Tessier et al., 1994). If metals are detoxified primarily by excretion, body concentrations should decrease when previously exposed individuals were transferred to a clean environment. However, if an element is bound in an inorganic matrix or to organic ligands, metal levels may remain constant, even after the exposure has ceased (Spurgeon and Hopkin, 1999). Animals exposed to high concentrations of metals over a long period, the storage capacity of the hepatopancreas may become saturated, allowing metals to pass into the haemolymph and interfere with sensitive biochemical processes (Spurgeon and Hopkin, 1999).

Heavy metals are strongly bound to soils rich in organic matter or clay (Sauve, 2002) and simultaneously earthworm developed specific trafficking, storage pathways and redistribution capacity to regulate the heavy metals, especially essential trace metals such as $\mathrm{Cu}$ and $\mathrm{Zn}$, in their bodies that may lead to balance between uptake and excretion (Dallinger, 1993; Morgan and Morgan, 1999). The regulatory capacity of 
metals can partly explain the ability of some earthworm species, like D. octaedra, to live even in a highly metal contaminated areas. Thus, the metal regulation may also have contributed to the development of metal resistance observed in some of the earthworm populations (Bengtsson et al., 1992; Langdon et al., 2001a, b; Reinecke et al., 1999). One additional factor that may reduce harmful effects of metals on the earthworms and also increase intraspecific variation in body burdens is heterogeneous distribution of metals in the soil (Lukkari et al., 2004).

\section{Conclusion}

Earthworms form the base of various food chains because they are preyed on by many species of snakes, mammals, and invertebrates (Edwards and Bohlen, 1996) and could increase biomagnification in various trophic levels of the food chain. This whole concept can upset the food chain as well as the food web. Increasing pollution and spontaneous addition of pollutant to soil through anthropogenic sources can alter growth, feeding, regeneration and respiration of $E$. fetida by both direct and indirect effects. These physiological activities of worm can be impaired by direct toxic effects of metals or by bringing changes in the energy budget as an individual attempts to prevent accumulation in sensitive tissues. In earthworms, cadmium, lead, and some zinc are detoxified by binding in granules (chloragocytes) or metallothionein like proteins in the chloragogenous tissue (Morgan and Morgan, 1988b; Morgan et al., 1989). In contrast, copper and the remaining zinc are eliminated by an excretion mechanism (Morgan and Morgan, 1990, 1991). The mechanisms of metal sequestration and elimination have metabolic costs in both development of the system and for the maintenance and repair. This increased the requirement for maintenance energy will ultimately result in a reduction in the energy available for growth and development (Donker et al., 1993a). If there is an increased energy demand for metal sequestration and elimination, this will decrease the energy available for other physiological activity and ultimately affects the organism. Present findings very much evident and transparent about the sensitivity of the worm E. fetida towards metallic contamination and indicates juvenile E. fetida is more sensitive to metal-contaminated soils than that of mature worms (Spurgeon and Hopkin, 1996). After 4-5 weeks of culture significant reduction was marked in the weight, feeding activity and regeneration capacity of the worm. In contradiction, rate of respiration clearly increases by the increasing of exposure duration with concentration dose. Number of studies on other soil dwelling invertebrates also suggests a clear reduction in growth on exposure to metal-contaminated diets due to avoidance of contaminated food (Drobne and Hopkin, 1995; Laskowski and Hopkin, 1996). In contradiction to our study Podolak et al. (2011) stated that metals may be either regulated $(\mathrm{Zn})$ or accumulated $(\mathrm{Ni}, \mathrm{Pb})$ in worm bodies, with or without deleterious effects on body weights, immune competent cells and physiological activity putatively due to their differential impact on soil and coelom-inhabiting microbes. For last few years, phosphogypsum is being used in agricultural soil as a calcium supplement to enhance the crop production (Nayak et al., 2011). Mullino and Mitchell (1990) have reported the use of phosphogypsum to increase yield and quality of forages in Florida. But respiration of soil was deeply affected by phosphogypsum application (Delaune et al., 2006) which directly hampers the physiological activities of soil dwelling organisms including earthworms. However, the chemical and biological response of soil to the waste amendment needs to be thoroughly investigated before recommending its large 
scale field application. When it comes to statistical part to verify the significance of phosphogypsum on Eisenia fetida (at 0.01 significance level), it was clearly significant. All the physiological activity of the earthworm was significantly hampered due to phosphogypsum and it was almost lethal. The heavy metallic constituents of phosphogypsum adversely affect the growth, feeding, respiration and regeneration activity of the worm.

Nevertheless earthworm based assessment is complicated by the fact that earthworms can develop tolerance to various pollutants, as documented in several studies of populations that have been in contact with high polluting sources over long periods (Bengtsson et al., 1992; Morgan and Morgan, 1992). The direct measurement of heavy metal concentrations in earthworm tissues could provide a means of assessing environmental pollution levels, given the demonstrated correlation between soil contamination and earthworm metal bioaccumulation (Motalib et al., 1997). But here the matter of concern is to generalize these vital facts regarding impact of heavy metals upon soil macrofauna in particular earthworms and standardize the accumulation range. How much and how far earthworms are able to tolerate such wide range and hazardous impact of heavy metals with varying composition of soil. This is a big question to answer. It becomes more necessary to generalize these facts and must be much more aware and watchful towards soil contamination.

\section{REFERENCES}

[1] Abdul Rida, A. A. M., Bouche, M. B. (1995): The eradication of an earthworm genus by heavy metals in southern France. - Appl. Soil Ecol. 2: 45-52.

[2] Agbaire, P. O., Emoyan, O. O. (2012): Bioaccumulation of heavy metals by earthworm (Lumbricus terrestris) and associated soils in domestic dumpsite in Abraka, Delta state, Nigeria. - Int. J. of Plant, Animal and Env. Sci. 2(3): 204-209.

[3] Akinrinde, E. A., Obigbesan, G. O., Onanuga, O. A. (2005): Extractable micronutrients in relation to physiochemical properties of soils in four ecological zones of Nigeria. Global Journal of Pure and Applied Sciences. 11(2): 197-200.

[4] Alloway, B. J. (1996): Heavy Metal in Soils. - Halsted Press, John Wiley and Sons Inc., London.

[5] Amorim, M. J. B., Rombke, J., Soares, A. (2005): Avoidance behaviour of Enchytraeus albidus: effects of benomyl, carbendazim, phenmedipham and different soil types. Chemosphere 59: 501-510.

[6] Avila, G. G., Gaete, H. H., Sauve, S. S., Neaman, A. A. (2009): Organic matter reduces copper toxicity for the earthworm Eisenia fetida in soils from mining areas in central Chile. - Chilean Journal of Agricultural Research 69: 252-259.

[7] Bamgbose, O., Odukoya, O., Arowolo, T. (2000): Earthworms as bio-indicators of metal pollution in dump sites of Abeokuta City, Nigeria. - Revista de Biologia Tropical 48: 229-234.

[8] Bengtsson, G., Gunnarsson, T., Rungren, S. (1986): Effects of metal pollution on the earthworm Dendrobaena ruhida (Sav.) in acidified soils. - Water Air Soil Pollut. 28: 361 83.

[9] Bengtsson, G., Nordstorm, S., Rundgren, S. (1981): Population density and tissue metal concentration of lumbricids in forest soils near a brass mill. - Environmental Pollution 30: $87-108$.

[10] Bengtsson, G., Nordstrom, S., Rundgren, S. (1986): Population density and tissue metal concentration of Lumbricids in forest soils near a Brass mill. - Environmental Pollution 30A: 87-108. 
[11] Bengtsson, G., Ek, H., Rundgren, S. (1992): Evolutionary response of earthworms to long-term metal exposure. - Oikos 63: 289-297.

[12] Berthelot, Y., Valton, E., Auroy, A., Trottier, B., Robidoux, P. Y. (2008): Integration of toxicological and chemical tools to assess the bioavailability of metals and energetic compounds in contaminated soils. - Chemosphere 74: 166-177.

[13] Brady, N. C. (1990): The Nature and Properties of Soils. 10th ed. - Macmillan, New York.

[14] Brewer, S., Barrett, G. (1995): Heavy metal concentrations in earthworms following long-term nutrient enrichment. - Bulletin of Environmental Contamination and Toxicology 54: 120-127.

[15] Callahan, C. A., Minzie, C. A., Burmaster, D. E., Willborn, D. C., Ernst, T. (1991): Onsite methods for assessing chemical impact on the soil environment using earthworms: A case study at the Baird and McGuire superfund site Holbrook, Massachusetts. Environ Toxicol Chem 10: 817-826.

[16] Central Pollution Control Board (2012): Hazardous Waste Management Series. HAZWAMS/2012-2013.

[17] Chen, L., Kost, D., Tian, Y., Guo, X., Watts, T., Norton, D., Richard, P. Wolkowski, Dick, W. A.(2014): Effects of gypsum on trace metals in soils and earthworms. - Journal of Environmental Quality 43: 263-272.

[18] Ching, Y. H., Xiaoming, Z., Carlos, R. (2006): Earthworm Invasions in the Tropics. - In: Nentwig, W. (ed.) Biological Invasions. Springer, Amsterdam.

[19] Dada, E. O., Njoku, K. L., Osuntoki, A. A., Akinola, M. O. (2013): Evaluation of the responses of a wetland, tropical earthworm to heavy metal contaminated soil. - Int. J of Env. Monitoring and Analysis 1(2): 47-52.

[20] Dallinger, R. (1993): Strategies of Metal Detoxification in Terrestrial Invertebrates. - In: Dallinger, R., Rainbow, P. S. (eds.) Ecotoxicology of Metals in Invertebrates. - Lewis Publishers, Chelsea, pp. 245-289.

[21] Davies, N. A., Hodson, M. E., Black, S. (2003): The influence of time on lead toxicity and bioaccumulation determined by the OECD earthworm toxicity test. - Environmental Pollution 121: 55-61.

[22] Delaune, R. D., Porthouse, J. D., Patrick, W. H. (2006): Effect of phosphogypsum on respiration and methane emissions in sediment. - Environ. Tech. 27: 575-584.

[23] Donker, M. H., Zonneveld, C., Van Straalen, N. M. (1993a): Early the terrestrial isopod Porcellio scaber. - Oecologia 96: 316-323.

[24] Drobne, D., Hopkin, S. P. (1995): The toxicity of zinc to terrestrial Isopods in a "standard" laboratory test. - Ecotoxicol. Environ. Saf. 31: 1-6.

[25] Duffy, J. E., Gulledge, J. (2011): Food Web. - In: Cleveland, C. J. (ed.) Encyclopedia of Earth. Environmental Information Coalition, National Council for Science and the Environment, Washington, DC. http://www. eoearth.org/article/Food_web (accessed 12 July 2012).

[26] Dutkiewicz, R., Klimek, M., Klimek, B., Stefanowicz, A. M., Plytycz, B. (2009): Effects of cadmium, copper, lead or nickel-contaminated soil on amoebocytes of the earthworm, Aporrectodea caliginosa. -Acta Biol. Crac. Ser. Zool. 51: 73-79.

[27] Edwards, C. A., Bater, J. E. (1992): The use of earthworms in environmental management. - Soil Biol. Biochem. 24: 1683-1689.

[28] Edwards, C. A., Bohlen, P. J. (1996): Biology and Ecology of Earthworms. - Chapman and Hall, London.

[29] Edwards, C. A., Bohlen, P. J., Linden, D. R., Subler, S. (1995): Earthworms in Agroecosystems. - In: Hendrix, P. F. (ed.), Earthworm Ecology and Biogeography in North America. Lewis Publishers, Boca Raton, FL, pp. 185-213.

[30] Fenoglio, S., Cucco, M., Gay, P., Malacarne, G. (2007): Colonisation by ground and edaphic invertebrates of soil patches with different pollution levels. - Periodicum Biologorum 109: 37-45. 
[31] Fordsmand, S. J. J., Weeks, M. J., Hopkin, S. P. (1998): Toxicity of nickel to the earthworm and the applicability of the neutral red retention assay. - Ecotoxicology 7(5): 291-95.

[32] Garg, V. K., Gupta, R., Kaushik, P. (2009): Vermicomposting of solid textile mill sludge spiked with cow dung and horse dung: a pilot scale study. - Int. J. Environ. and Poll. 38(4): 385-396.

[33] Gates, G. (1949): Regeneration in an earthworm, Eisenia foetida (Savigny) 1826. I. Anterior regeneration. - The Biological Bulletin 96(2): 129-139.

[34] Gestel, C. A. M., Dis, W. A. (1988): The influence of soil characteristics on the toxicity of four chemicals to the earthworm Eisenia andrei (Oligochaeta). - Biol. Fertil. Soils 6: 262-265.

[35] Gestel, C. A. M., Van, D., Van, W. A., Breemen, E. M., Sparenburg, P. M. (1989): Development of a standardized reproduction toxicity test with the earthworm species Eisenia andrei using copper, pentachlorophenol and 2.4- dichloroaniline. - Ecotoxicol. Environ Safety 18: 305-12.

[36] Gestel, C. A. M., Van, D., Van, W. A., Breemen, E. M., Sparenburg, P. M., Baerselem, R. (1991): Influence of cadmium, copper and pentachlorophenol on growth and sexual development of Eisenia andrei (Oligochaete: Annelida). - Biol. Fertil. Soils 12: 117-21.

[37] Gestel, C. A. M. Van, D., Breemen, E. M., Baerselman, R., Emans, H. J. B., Janssen, J. A. M., Postuma, R., Vliet, P. J. M., Van, V. P. J. (1992): Comparison of sublethal and lethal criteria for nine different chemicals in standardized toxicity tests using the earthworm Eisenia andrei. Ecotoxicol. - Environ. Safety 23(2): 206-20.

[38] Goats, G. C., Edwards, C. A. (1982): Testing the toxicity of industrial chemicals to earthworms. - Rothamsted Exp Stn Rep. 1982: 104-105.

[39] Grzes, I. M.(2009): Ant species richness and evenness increase along a metal pollution gradient in the Bolesław zinc smelter area. - Pedobiologia 53: 65-73.

[40] Gunta, M. L., Sakal, R. (1967): Role of earthworms on availability of nutrients in garden and cultivated soils. - Journal of the Indian Society of Soil Science 15: 149-151.

[41] Haghparast, R. J., Golchin, A., Kahneh, E. (2013): Effect of Different Cadmium Concentrations on Growth of Eisenia fetida in a Calcareous Soil. - Journal of Water and Soil 27(1): 24-35.

[42] Honsi, T. G., Stubberud, H. E., Andersen, S., Stenersen, J.(2003): Lysosomal fragility in earthworms (Eisenia Veneta) exposed to heavy metal contaminated soils from two abandoned pyrite ore mines in southern Norway. - Water, Air and Soil Pollution 142: 2737.

[43] International Organization for Standardization (ISO 11268-2) (1998): Soil quality Effects of pollutants on earthworms. Part 2: Determination of effects on reproduction of Eisenia fetida/ Eisenia andrei. - ISO, Geneva.

[44] Irizar, A., Rodríguez, M., Izquierdo, A., Cancio, I., Marigómez, I., Soto, M. (2015): Effects of soil organic matter content on cadmium toxicity in Eisenia Fetida: Implications for the use of biomarkers and standard toxicity tests. - Archives of Environmental Contamination and Toxicology 68: 181-192.

[45] Joshi, D. C., Dhir, R. P., Gupta, B. S. (1983): Influence of soil parameters on DTPA extractable micronutrients in arid soils. - Plant and Soil 72(1): 31-38.

[46] Kaur, G., Hundal, S. S. (2016): Effect of heavy metals on the survival, growth and development of earthworm Eisenia fetida. - Journal of Applied and Natural Science 8(1): 208-212.

[47] Kennette, D., Hendershot, W., Tomlin, A., Sauve, S. (2002): Uptake of trace metals by the earthworm Lumbricus terrestrist in urban contaminated Soil. - Applied soil Ecology 19: 191-198.

[48] Khalil, A. M. (2013): Ecotoxicological bioassays of the earthworms Allolobophora caliginosa savigny and Pheretima hawayana rosa treated with arsenate. - On Line Journal of Biological Sciences 13(3): 99-105. 
[49] Kobeticova, K., Hofman, J., Holoubek, I. (2010): Ecotoxicity of wastes in avoidance tests with Enchytraeus albidus, Enchytraeus crypticus and Eisenia fetida (Oligochaeta). Waste Management 30(4): 558-64.

[50] Kwadrans, A., Litwa, J., Woloszczakiewicz, S., Ksiezarczyk, E., Klimek, M., Duchnowski, M.(2008): Changes in coelomocytes of the earthworm, Dendrobaena veneta, exposed to cadmium, copper, lead or nickel-contaminated soil. - Acta Biol. Crac. Ser. Zool. 49: 57-62.

[51] Langdon, C. J., Piearce, T. G., Meharg, A. A., Semple, K. T. (2001a): Survival and behavior of the earthworms Lumbricus rubellus and Dendrodrilus rubidus from arsenatecontaminated and non-contaminated sites. - Soil Biol. Biochem. 33: 1239-1244.

[52] Langdon, C. J., Piearce, T. G., Meharg, A. A., Semple, K. T. (2001b): Resistance to copper toxicity in populations of the earthworms Lumbricus rubellus and Dendrodrilus rubidus from contaminated mine wastes. - Environ. Toxicol. Chem. 20: 2336-2341.

[53] Laskowski, R., Hopkin, S. P. (1996): Effects of $\mathrm{Zn}, \mathrm{Cu}, \mathrm{Pb}$ and $\mathrm{Cd}$ on fitness in snails (Helix aspersa). - Ecotoxicol. Environ. Saf. 34: 59-69.

[54] Lavelle, P. (1988): Earthworms activity in the soil system. - Biol. Fertil. Soil. 6: 237-251.

[55] Leduca, F., Whalena, J.K, Sunahara, G. I. (2008): Growth and reproduction of the earthworm Eisenia fetida after exposure to leachate from wood preservatives. Ecotoxicology and Environmental Safety 69: 219-226.

[56] Lee, C. H., Ha, B. Y., Lee, Y. B., Kim, P. J.(2009): Effect of alkalized Phosphogypsum on soil chemical and biological properties. - Communications in Soil Science and Plant Analysis 40: 2072-2086.

[57] Li, L., Xu, Z., Wu, J., Tian, G. (2010): Bioaccumulation of heavy metals in the earthworm Eisenia fetida in relation to bioavailable metal concentrations in pig manure. Bioresource Technology 101: 3430-3436.

[58] Li, Y., Ghodrati, M. (1995): Transport of nitrate in soil as affected by earthworm activities. - J. Environ. Qual. 24: 432.

[59] Lock, K., Janssen, C. R. (2002b): Ecotoxicity of chromium (III) to Eisenia fetida, Enchytraeus albidus, and Folsomia candida. - Ecotoxicol. Environ. Saf. 51: 203-205.

[60] Lukkari, T., Taavitsainen, M., Vaisanen, A., Haimi, J. (2004): Effects of heavy metals on earthworms along contamination gradients in organic rich soils. - Ecotoxicology and Environmental Safety 59: 340-348.

[61] Lunt, H. A., Jacobson, H. G. M. (1944): The chemical composition of earthworm casts. Soil Science 58: 367-375.

[62] Ma, W., Edelman, T., Van Beersum, I., Jans, T. (1983): Uptake of cadmium, zinc, lead, and copper by earthworms near a zinc-smelting complex: influence of soil $\mathrm{pH}$ and organic matter. - Bulletin of Environmental Contamination and Toxicology 30(1): 424427.

[63] Malecki, M. R., Neuhauser, E. F., Loehr, R. C. (1982): The effect of metals on the growth and reproduction of Eisenia foetida (Oligochaeta, Lumbricidae). - Pedobiologia 24: 129137.

[64] Matuseviciute, A., Eitminavicivte, I. (2005): Effects of different cadmium concertrations on survival, reproduction and adaptation of Eisenia fetida Californica. - Acta Zoologica Litvanica 15: 361-369.

[65] Miguel, A., Dominguez, C. Z., Hernández, E. S., Aide, M., Huerta, T., De la Luz, X. M., Rodriguez, N., Barajas, C. E., Vela, A. F. (2012): Effect of the heavy metals Cu, Ni, Cd and $\mathrm{Zn}$ on the growth and reproduction of epigeic earthworms (E. fetida) during the vermistabilization of municipal sewage sludge. - Water, Air and Soil Pollution 223(2): 915-931.

[66] Mishra, P. C., Sahoo, S. (1989): Agro Potentiality of Paper Mill Wastewater. - In: Mishra, P. C. (ed.) Soil Pollution and Soil Organisms. Ashis Publ House, New Delhi, pp. 97-119. 
[67] Mishra, P. C., Sahoo, S. (1997): Production and energetics of earthworm population (Lampito mauritii, Kinberg) and metabolism in soil under paper mill wastewater irrigation. - Ecol Environ Cons 3: 49-61.

[68] Morgan, J. E., Morgan, A. J. (1988a): Seasonal change in the tissue metals (Cd, Zn and $\mathrm{Pb}$ ). Concentration in two Ecophysiolgoically dissimitar earthworms species. Pollution monitoring implication. - Environ. and Pollut. 82: 1-7.

[69] Morgan, J. E., Morgan, A. J. (1988b): Earthworms as biological monitors of cadmium, copper, lead and zinc in metalliferous soils. - Environmental Pollution 54: 123-138.

[70] Morgan, J. E., Morgan, A. J. (1990): The distribution of cadmium copper, lead, zinc and calcium in the tissue of the earthworm Lumbricus rubellus. - Oecologia 84: 559-566.

[71] Morgan, J. E., Morgan, A. J. (1991): Differences in the accumulated metal concentrations in two epigeic earthworm species (L. rubellus and D. rubidus) living in contaminated soils. Bull. Environ. - Contam. Toxicol. 47: 296-301.

[72] Morgan, J. E., Morgan, A. J. (1992): Heavy metal concentrations in the tissues, ingesta, ingesta and faeces of physiologically different earthworm species. - Soil Biol. Biochem. 24(12): 1691-1697.

[73] Morgan, J. E., Morgan, A. J. (1999): The accumulation of metals (Cd, Cu, Pb, $\mathrm{Zn}$ and $\mathrm{Ca}$ ) by two ecological contrasting earthworm species (lumbricus Rubellus and Aporrectodea calignosa); implications for ecotoxicological testing. - Applied Soil Ecology 13: 9-20.

[74] Morgan, J. E., Norey, C. G., Morgan, A. J., Kay, J. (1989): A comparison of the cadmium-binding proteins isolated from the posterior alimentary canal of the earthworms Dendrodrilus rubidus and Lumbricus rubellus. - Comparative Biochemistry and Physiology. Part C: Comparative Pharmacology 92C: 15-21.

[75] Motalib, A., Rida, M. A., Bouché, M. B. (1997): Heavy metal linkages with mineral, organic, organic and living soil compartments. - Soil Biol. Biochem. 29: 649-655.

[76] Mountouris, A., Voutsas, E., Tassios, D. (2002): Bioconcentration of heavy metals in aquatic environments: the importance of bioavailability. - Marine Pollution Bulletin 44: 1136-1141.

[77] Mullino, G. L., Mitchell, C. C. (1990): Use of Phosphogypsum to Increase Yield and Quality of Annual Forages. - Publ. of Florida Inst. of Phosph. Research, Bartoe, Florida.

[78] Nahmani, J., Patrick, L., Emmanuel, L., Folkert, V. (2003): Effect of heavy metal pollution on earthworm communities in the north of France: The 7th international symposium on earthworm ecology. - Pedobiologia 47(5-6): 663-669.

[79] Nahmani, J., Hodson, M. E., Black, S. (2007): A review of studies to assess metal uptake by earthworms. - Environmental Pollution 145: 402-424.

[80] Nayak, S., Mishra, C. S. K., Guru, B. C., Rath, M. (2011): Effect of phosphogypsum amendment on soil physico-chemical properties, microbial load and enzyme activities. Journal of Environmental Biology 32: 613-617.

[81] Neuhauser, E. F., Loehr, R. C., Miligan, D. L., Malecki, M. R. (1985): Toxicity of metals to the earthworm Eisenia fetida. - Biology and Fertility of Soils 1: 149-152.

[82] Nwuche, C. O., Ugoji, E. O. (2008): Effects of heavy metal pollution on the soil microbial activity. - Int. J. Environ. Sci. Tech. 5(3): 409-414.

[83] Odoh, R., Agbaji, E. B., Kagbu, J. A., Thomas, S. A. (2011): Heavy metal speciation in agricultural farmland in some selected local government areas of Benue state, Nigeria. Archives of Applied Science Research 3(3): 560-573.

[84] OECD Guideline for Testing Chemicals 207 (1984): Earthworm Acute Toxicity Test. Adopted: 4 April 1984. - OECD, Paris.

[85] Olaniya, M. S., Bhoyar, R. V., Bhide, A. D. (1991): Effect of solid waste disposal on land. - Indian J. Environ, Tilth. 34: 143-149.

[86] Olchawa, E., Bzowska, M., Stürzenbaum, S. R., Morgan, A. J., Peytycz, B.(2006): Heavy metals affect the coelomocyte-bacteria balance in earthworms: Environmental interactions between abiotic and biotic stressors. - Environ. Pollut. 142: 373-381. 
[87] Otitoloju, A. A., Ajikobi, D. O., Egonmwan, R. I.(2009): Histopathology and Bioaccumulation of Heavy Metals $(\mathrm{Cu} \& \mathrm{~Pb})$ in the Giant land snail, Archachatina marginata (Swainson). - The Open Environmental Pollution \& Toxicology Journal 1: 7988.

[88] Owojori, O. J., Reinecke, A. J., Rozanov, A. B. (2009): Role of clay content in partitioning, uptake and toxicity of zinc in the earthworm Eisenia fetida. - Ecotoxicol. Environ. Safe. 72(1): 99-107.

[89] Parle, J. N. (1963): A microbiological study of earthworm casts. - Journal of Geneal Microbiology 31: 13-22.

[90] Podolak, A., Piotrowska, E., Klimek, M., Klimek, B. A., Kruk, J., Plytycz, B. (2011): Effects of Nickel, Zinc, and Lead-Contaminated Soil on Burrowing Rate and Coelomocytes of the Earthworm, Allolobophora chlorotica. - Foliabiologica (Kraków) 59: 3-4.

[91] Radha, D. K., Natchimuthu, K. (2010): The role of earthworms in tropics with emphasis on Indian ecosystems. - Appl. Environ. Soil Sci. Review. DOI: 10.1155/2010/414356.

[92] Rakhimova, A., Khussainov, A., Grinfelde, I. (2017): Impact of coal ash and phosphogypsum application on soil fertility of chernozem soils of north Kazakhstan. Engineering for Rural Development Jelgava 24: 1047-1051.

[93] Reinecke, A. J., Reinecke, S. A., Maboeta, M. S. (2001): Cocoon production and viability as endpoints in toxicity testing of heavy metals with three earthworm species. Pedobiologia 45: 61-68.

[94] Reinecke, S. A., Prinsloo, M. W., Reinecke, A. J. (1999): Resistance of Eisenia fetida (Oligochaeta) to cadmium after long-term exposure. - Ecotoxicol. Environ. Saf. 42: 7580.

[95] Remmert, H. (1980): Ecology A Text Book. - Springer, Berlin.

[96] Rongquan, Z., Canyang, L. (2009): Effect of lead on survival, locomotion and sperm morphology of Asian earthworm, Pheretima guillelmi. - Journal of Environmental Sciences 21(5): 691-695.

[97] Salice, C. J., Roesijadi, G. (2002): Resistance to cadmium and parasite infection are inversely related in two strains of a fresh water gastropod. Environ. - Toxicol. Chem. 21: 1398-1403.

[98] Sauve, S. (2002): Speciation of Metals in Soils. - In: Allen, H. E. (ed.) Bioavailability of Metals in Terrestrial Ecosystems: Importance of Partitioning for Bioavailability to Invertebrates, Microbes, and Plants. SETAC, Pensacola, pp. 7-38.

[99] Shahmansouri, M. R., Pourmoghadas, H., Parvaresh, A. R., Alidadi, H. (2005): Heavy metals bioaccumulation by Iranian and Australian earthworms (Eisenia fetida) in the sewage sludge vermicomposting. - Iranian J. Environmental Health Science and Engineering 2: 28-32.

[100] Sharma, R.P, Sharma, J. P., Megh, S. (2003): Correlation studies of Micronutreients visa-vis soil properties in some soils of Nagaur District in Semi-arid region of Rajasthan. Journal of Indian Society of Science 51(4): 522-527.

[101] Sivakumar, S., Subbhuraam, C. V. (2005): Toxicity of chromium(III) and chromium(VI) to the earthworm Eisenia fetida. - Ecotoxicol. Environ. Saf. 62: 93-98.

[102] Sizmur, T., Hodson, M. E. (2009): Do earthworms impact metal mobility and availability in soil? A review. - Environ. Pollut. 157(7): 1981-1989.

[103] Smith, R. G., McSwiney, C. P., Grandy, A. S., Suwanwaree, P., Snider, R. M., Robertson, G. P.(2008): Diversity and abundance of earthworms across an agricultural land-use intensity gradient. - Soil Till. Res. 100: 83-88.

[104] Spurgeon, D. J., Hopkin, S. P. (1996): Effects of metal-contaminated soils on the growth, sexual development and early cocoon production of the earthworm Eisenia fetida, with particular reference to zinc. - Ecotoxicology and Environmental Safety 35: 86-95.

[105] Spurgeon, D. J., Hopkin, S. P., Jones, D. T. (1994): Effects of cadmium, copper, lead and zinc on growth, reproduction and survival of the earthworm Eisenia fetida (Savigny): 
assessing the environmental impact of point-source metal contamination in terrestrial ecosystems. - Environmental Pollution 84: 123-130.

[106] Spurgeon, D. J., Weeks, J. M., Van Gestel, C. A. M. (2003): A summary of eleven years progress in earthworm ecotoxicology. - Pedobiol. 47: 588-606.

[107] Spurgeon, D. J., Sturzenbaum, S. R., Svendsen, C., Hankard, P. K., Morgan, A. J., Weeks, J. M., Kille, P. (2004a): Toxicological, cellular and gene expression responses in earthworms exposed to copper and cadmium. - Comparative Biochemistry and Physiology. Part C: Comparative Pharmacology 138: 11-21.

[108] Spurgeon, D. J., Svendsen, C., Kille, P., Morgan, A. J., Weeks, J. M. (2004b): Responses of earthworms (Lumbricus rubellus) to copper and cadmium as determined by measurement of juvenile traits in a specifically designed test system. - Ecotoxicology and Environmental Safety 57: 54-64.

[109] Spurgeon, D. J., Ricketts, H., Svendsen, C., Morgan, A. J., Kille, P. (2005): Hierarchical responses of soil invertebrates (earthworms) to toxic metal stress. - Environmental Science and Technology 39: 5327-5334.

[110] Spurgeon, H. A., Dubell, W. H., Stern, M. D., Sollott, S. J., Ziman, B. D., Silverman, H. S., Capogrossi, M. C., Talo, A., Lakatta, E. G. (1992): Cytosolic calcium and myofilaments in single rat cardiac myocytes achieve a dynamic equilibrium during twitch relaxation. - Journal of Physiology 447: 83-10.

[111] Spurgeona, D. J., Hopkin, S. P. (1999): Comparisons of metal accumulation and excretion kinetics in earthworms (Eisenia fetida) exposed to contaminated field and laboratory soils. - Applied Soil Ecology 11: 227-243.

[112] Stockdill, S. (1982): Effects of introduced earthworms on the productivity of New Zealand pastures. - Pedobiologia (Jena) 24: 29-35.

[113] Syers, J. K., Springett, J. A. (1984): Earthworms and soil fertility. - PIant and Soil 76: 93-104.

[114] Syers, J. K., Sharpley, A. N., Keeney, D. R. (1979): Cycling of nitrogen by surfacecasting earthworms in a pasture ecosystem. - Soil Biology \& Biochemistry 11: 181-185.

[115] Tessier, L., Vaillancourt, G., Pazdernik, L. (1994): Temperature effects on cadmium and mercury kinetics in freshwater mollusks under laboratory conditions. - Arch. Environ. Contam. Toxicol. 26: 179-184.

[116] Tiwari, S. C., Tiwari, B. K., Mishra, R. R. (1989): Microbial populations, enzyme activities and nitrogen-phosphorus-potassium enrichment in earthworm casts and in the surrounding soil of a pineapple plantation. - Biology and Fertility of Soils 8: 178-182.

[117] Van Gestel, C. A. M., Dirven-van Breemen, E. M., Baerselman, R., Emans, H. J. B., Janssen, J. A. M., Postuma, R., van Vliet, P. J. M. (1992): Comparison of sublethal and lethal criteria for nine diff erent chemicals in standardized toxicity tests using the earthworm Eisenia andrei. - Ecotoxicology and Environmental Safety 23: 206-220.

[118] Van Gestel, C. A. M., Koolhaas, J. E., Hamers, T., van Hopper, M., van Roovert, M., Korsman, C., Reinecke, S. A. (2009): Effects of metal pollution on earthworm communities in a contaminated fl oodplain area: linking biomarker, community and functional responses. - Environmental Pollution 157: 895-903.

[119] Wen, B., Hu, X., Liu, Y., Wang, W., Feng, M., Shan, X. (2004): The role of earthworms (Eisenia fetida) in influencing bioavailability of heavy metals in soils. - Biol. Fertil. Soils 40: 181-189.

[120] Wieczorek-olchawa, E., Niklinska, M., Miedzo-brodzki, J., Plytycz, B. (2003): Effects of temperature and soil pollutions on the presence of bacteria, coelomocytes and brown bodies in coelomic fluid of Dendrobaena veneta. - Pedobiologia 47: 702-709.

[121] Willems, J., Marmissen, J., Blair, J. (1996): Effects of earthworms on nitrogen mineralization. - Biol. Fertil. Soils 23: 57-63.

[122] Witkamp, M. (1966): Rates of CO2 evolution from forest floor. - Ecology 7: 492-494. 
[123] Zachary, A. H., Reid, B. J. (2008): The co-application of earthworms (Dendrobaena veneta) and compost to increase hydrocarbon losses from diesel contaminated soils. Environment International 34(7): 1016-1022.

[124] Zaltauskaite, J., Sodiene, I. (2010): Effects of total cadmium and lead concentrations in soil on the growth, reproduction and survival of earthworm. - Ekologija 56(1-2): 10-16. 